\title{
Allelopathic and Autotoxic Effects of Medicago sativa-Derived Allelochemicals
}

\author{
Bimal Kumar Ghimire ${ }^{1}$, Balkrishna Ghimire ${ }^{2}$, Chang Yeon $\mathrm{Yu}^{3}$ and Ill-Min Chung ${ }^{1, *}$ \\ 1 Department of Applied Life Science, Konkuk University, Seoul 05025, Korea \\ 2 Division of Plant Resources, Korea National Arboretum, Pocheon 11186, Korea \\ 3 Department of Agriculture Life Sciences, Kangwon National University, Chuncheon 24341, Korea \\ * Correspondence: imcim@konkuk.ac.kr
}

Received: 10 June 2019; Accepted: 16 July 2019; Published: 18 July 2019

\begin{abstract}
In this study, the allelopathic properties of Medicago sativa on different weeds were investigated under in vitro conditions. The compounds involved in the autotoxicity of $M$. sativa were analyzed using high-performance liquid chromatography. The extracts of all concentrations inhibited the growth of the calluses of Digitaria ciliaris, Chenopodium album, Amaranthus lividus, Portulaca oleracea, and Commelina communis. Six allelopathic compounds in alfalfa were identified and quantified, and the most predominant phenolic compounds were salicylic acid and $p$-hydroxybenzoic acid. Various concentrations $\left(10^{-2}, 10^{-3}\right.$, and $\left.10^{-5} \mathrm{M}\right)$ of all the tested phenolic compounds exerted inhibitory effects on callus fresh weight. Rutin, salicylic acid, scopoletin, and quercetin significantly inhibited alfalfa seed germination. Of the seven identified saponins, medicagenic acid saponins exhibited the highest autotoxic effect and significantly lowered seed germination rate. Principal component analysis showed that the phenolic compounds and saponin composition significantly contributed to the different variables. The highly phytotoxic properties of the alfalfa-derived phenolic compounds and saponins indicate that these phytochemicals can be a potential source of bioherbicides.
\end{abstract}

Keywords: allelopathic properties; callus growth; alfalfa leaf extracts; saponins; phenolic compounds; nuclear magnetic resonance

\section{Introduction}

Numerous methods for weed management in different systems have been developed over the decades. Of these, herbicide use and hand and mechanical weeding are the most reliable weed control methods [1-3]. Herbicides use is increasingly being adopted for weed control and for increasing crop production [4]. However, herbicide-resistant weeds are the major constraint to weed control in modern agriculture. Additionally, hand weeding and mechanical weed control methods are expensive and labor intensive [5-7]. Furthermore, weed control via chemical herbicide use reportedly negatively impacts the environment and human health [8-14]. Extensive exposure to chemical herbicides may cause numerous health issues such as reproductive problems, neurologic impairment, pancreatic cancer, immune malfunction, and silicosis [15]. Furthermore, herbicides are unaffordable to small-scale farmers and unsuitable for organic farming. These challenges associated with the use of herbicides and mechanical weed control methods in land cultivation make it imperative to develop novel, environmentally friendly methods. The global interest in alternative, sustainable, and innovative technologies for weed management that not only reduce chemical herbicide use but are also environmentally and health-friendly and decrease agricultural production cost is increasing.

Allelopathy is defined as the direct/indirect harmful/beneficial effect of one plant on another via the production of chemical compounds that escape into the environment. Allelochemicals are generally secondary plant metabolites, which are part of a wide range of chemicals synthesized by plants, not 
directly involved in plant growth and development. Nowadays, allelopathic plants are being used for weed control and natural herbicide development. The environmental- and biodiversity-conserving nature of allelopathic weed control has made it more popular than mechanical methods and chemical herbicides. Some plant species exude useful biochemicals (also called allelochemicals or phytochemicals) that inhibit/suppress seed germination and weed growth $[16,17]$. These phytochemicals are generally phenolics (such as tannins), alkaloids, steroids, terpenes, saponins, and quinones that affect the growth and development of certain plant species [18]. The mechanism of action of some allelochemicals is similar to that of chemical herbicides, making them ideal for weed management. The allelochemicals produced by donor plants are often detrimental to their own species-an autotoxic effect [19]. These phytochemicals are totally/partially water soluble, making them more environmentally friendly than chemical herbicides $[18,20]$. They are characterized by higher $\mathrm{O}_{2}$ - and $\mathrm{N}_{2}$-rich molecules and few halogen substitutes [19]. Allelopathy has a positive effect on soil, as it improves nutrient availability to crops by increasing microbial activity [21,22]. Allelochemicals are exuded from different plant parts at different ratios, and their exudation varies within different cultivars [23,24].

Both the allelopathic and autotoxic nature of plant species are useful for the invasion, distribution, and abundance of plants within the plant community [25-30]. The degree of allelopathy depends on disease, nutrition, insects, competition [31,32], biotic factors such as nutrients level, and abiotic factors such as temperature, irradiation, draught, and $\mathrm{pH}[33,34]$. Allelopathic and autotoxic compounds are released from donor plants as volatiles, roots exudates, or foliage leachates, and contain several secondary metabolites such as flavonoid phenolics [35], ketones, aldehydes, terpenoids, lactones, cinnamic acid, and quinines [36]. If these compounds are released into the soil by any plant, they may exert toxic effects on neighboring plants or aid the production of new toxins by soil microbes [37]. The mechanism of action of allelochemicals in neighboring plants depends on their effects, which could be synergistic, additive, or antagonistic [38-40].

Medicago sativa L. (Leguminosae), commonly called alfalfa, is a perennial herb mostly grown in America, Europe, and Asia [41]. It is used as a source of protein [42,43], fat, and crude fiber [44] and as hay, silage, and pasture [45,46]. Traditionally, its dried leaf is used to lower cholesterol levels [47]. Alfalfa reportedly contains several useful phytochemicals, including phenolic compounds, saponins, and medicarpin, which possess inhibitory properties against several plant seedlings [48]. Other important phytocompounds extracted from this species include linoleic and linolenic acid, vitamins, and iron compounds $[49,50]$. Although the allelopathic properties of alfalfa on weeds have been documented, the exact nature of the allelopathic phytochemicals and their mechanisms of action remain poorly understood.

The main objective of this study was to explore the possible allelopathic effects of alfalfa extracts on callus growth in some weed species. Furthermore, TLC, HPLC, and NMR methods were used to determine the major allelochemicals present in the alfalfa leaf extracts. Additionally, the autotoxic compounds in alfalfa were determined. We also elucidated the mechanism involved in seed germination inhibition by alfalfa leaf extracts and assessed the correlation between the allelochemicals exuded by alfalfa and the rate of alfalfa seed inhibition. It is worth mentioning that, to our knowledge, this is the first report on the allelopathic effect of alfalfa on callus growth in different weeds.

\section{Results}

\subsection{Effect of Alfalfa Leaf Extracts on Callus Induction}

The application of alfalfa leaf extracts influenced callus induction and fresh weight in the studied weeds in a varied manner (Figure 1). Alfalfa leaf extracts $(0.1 \mathrm{mg} / \mathrm{mL})$ significantly promoted callus induction in Digitaria ciliaris (Table 1). However, increasing the concentration to 5 and $10 \mathrm{mg} / \mathrm{mL}$, decreased the callus induction rate by twofold. All of the extract concentrations used decreased the callus induction rate in Chenopodium album in a concentration-dependent manner. The results also show that the callus of $C$. album was highly sensitive to $10 \mathrm{mg} / \mathrm{mL}$ alfalfa leaf extracts. The fresh weight of callus cultured in the Murashige and Skoog (MS) medium containing $5 \mathrm{mg} / \mathrm{mL}$ alfalfa leaf 
extract showed the highest suppression of callus induction in Amaranthus lividus and Portulaca oleracea. However, in these species, when the concentration of extracts was increased from 5 to $10 \mathrm{mg} / \mathrm{mL}$, a reverse trend was observed. Similarly, the alfalfa leaf extracts inhibited the callus growth and reduced the callus fresh weight in Commelina communis.
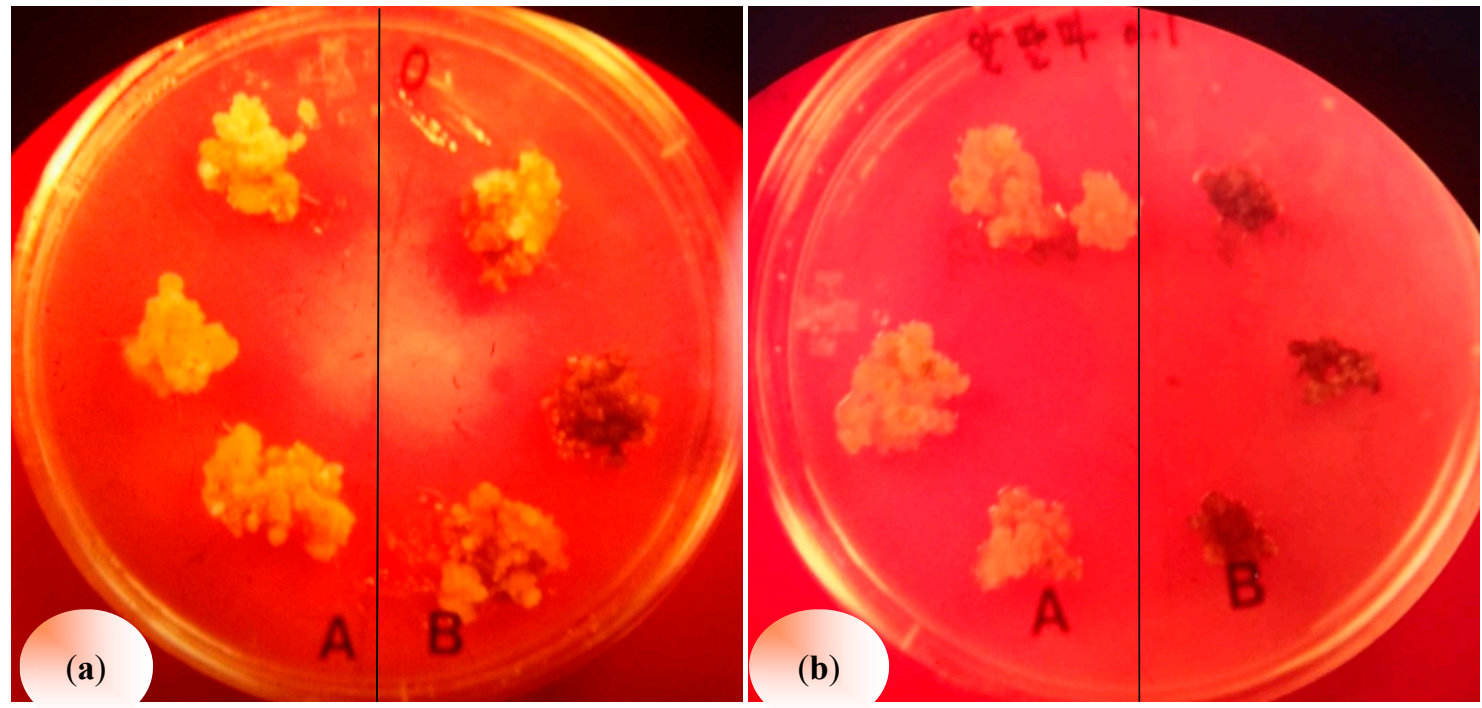

Figure 1. (A) Callus growth in the absence of alfalfa leaf extract. (a) Callus of C. album; (b) callus of $P$. oleracea. (B) Callus growth in the MS medium supplemented with $0.1 \%$ alfalfa leaf extract. (a) Callus of C. album; (b) callus of P. oleracea.

Table 1. Effect of alfalfa leaf extracts on callus fresh weight.

\begin{tabular}{|c|c|c|c|c|c|c|}
\hline Treatment & $\begin{array}{c}\text { Concentration } \\
(\%) .\end{array}$ & \multicolumn{5}{|c|}{ Callus Fresh Weight (mg) } \\
\hline Control & 0.1 & $345.50 \pm 4.00^{c}$ & $819.30 \pm 10.50^{c}$ & $125.50 \pm 4.00^{\mathrm{b}}$ & $610.40 \pm 5.00^{c}$ & $118.70 \pm 5.90^{c}$ \\
\hline \multirow[t]{2}{*}{ MS + Alfalfa } & 5 & $115.44 \pm 5.00^{\mathrm{a}}$ & $6.20 \pm 0.40^{b}$ & $100.50 \pm 2.50^{\mathrm{a}}$ & $100.80 \pm 6.80^{\mathrm{a}}$ & $99.40 \pm 3.90^{b}$ \\
\hline & 10 & $115.40 \pm 4.00^{\mathrm{a}}$ & $5.20 \pm 0.50^{\mathrm{a}}$ & $125.50 \pm 5.00^{b}$ & $105.80 \pm 5.90^{b}$ & $59.90 \pm 2.00^{a}$ \\
\hline
\end{tabular}

Data are expressed as mean \pm standard deviation $(n=3)$. Data with the same letter in a column are not significantly different, as determined using Duncan's multiple range test $(p<0.05)$. MS, Murashige and Skoog medium.

\subsection{Effect of Allelopathic Compounds on Callus Growth}

To determine the relationship between allelopathy and the phytochemical constituents of alfalfa, its phenolic compound concentration and composition were determined using HPLC (Table 2). Six active allelopathic compounds were identified and quantified, with salicylic and $p$-hydroxybenzoic acids being the most predominant phenolic compounds, accounting for $80.8 \%$ of the all phenolic compounds (Table 2). In this study, calluses were treated with six standard phenolic compounds to measure their effect on callus growth in P. oleracea, C. album, and Pinellia ternata. All concentrations $\left(10^{-2}\right.$, $10^{-3}$, and $10^{-5} \mathrm{M}$ ) of all the tested phenolic compounds showed inhibitory effects on callus fresh and dry weights. In particular, the callus of P. oleracea was highly sensitive to these phenolic compounds, compared with the other species. The lower concentration of salicylic acid $\left(10^{-5} \mathrm{M}\right)$ was very active and effectively inhibited $(26.90 \pm 2.50 \mathrm{mg})$ the callus growth and fresh weight of C. album. Ferulic acid $\left(10^{-2} \mathrm{M}\right)$ had the highest effect on P. oleracea, represented by the lower fresh weight and fresh weight percentage $\left(4.10 \pm 0.30 \mathrm{mg}\right.$ and $0.60 \% \pm 0.01 \%$, respectively). Similarly, salicylic acid $\left(10^{-2} \mathrm{M}\right)$ highly inhibited the callus fresh weight and fresh weight percentage of P. oleracea and C. album. Increasing the ferulic acid concentration from $10^{-5}$ to $10^{-3} \mathrm{M}$ had no effect on callus growth, as indicated by nonsignificant results (Table 3). Similar results were observed for $p$-coumaric and syringic acids. 
Table 2. Phenolic compounds in the alfalfa leaf extracts.

\begin{tabular}{cc}
\hline Name of Phenolic Compounds & Phenolic Compound Concentration $(\boldsymbol{\mu g} / \mathbf{m L})$ \\
\hline Salicylic acid & $1927.01 \pm 12.50^{\mathrm{f}}$ \\
$p$-Hydroxybenzoic acid & $372.01 \pm 5.00^{\mathrm{e}}$ \\
Vanillic acid & $137.50 \pm 6.50^{\mathrm{c}}$ \\
Syringic acid & $50.00 \pm 3.40^{\mathrm{a}}$ \\
$p$-Coumaric acid & $171.50 \pm 5.80^{\mathrm{d}}$ \\
Ferulic acid & $105.00 \pm 3.80^{\mathrm{b}}$ \\
Total & $2762.50 \pm 13.50 \mathrm{~g}$ \\
\hline
\end{tabular}

Data are expressed as mean \pm standard deviation $(n=3)$. Different small letters indicate a significant difference as determined using Duncan's multiple range test $(p<0.05)$

Table 3. Effect of standard phenolic compounds on callus fresh weight.

\begin{tabular}{|c|c|c|c|c|c|c|c|}
\hline \multirow[b]{2}{*}{ Chemical } & \multirow{2}{*}{ Concentration (M) } & \multicolumn{2}{|c|}{ Portulaca oleracea } & \multicolumn{2}{|c|}{ Chenopodium album } & \multicolumn{2}{|c|}{ Pinellia ternata } \\
\hline & & $\begin{array}{c}\text { Fresh Weight } \\
(\mathrm{mg})\end{array}$ & Fresh Weight (\%) & $\begin{array}{c}\text { Fresh Weight } \\
(\mathrm{mg})\end{array}$ & Fresh Weight (\%) & $\begin{array}{c}\text { Fresh Weight } \\
\text { (mg) }\end{array}$ & Fresh Weight (\%) \\
\hline \multirow{3}{*}{ Salicylic acid } & $10^{-5}$ & $140.10 \pm 4.00^{n}$ & $19.80 \pm 0.90 \mathrm{~m}$ & $26.90 \pm 2.50^{\mathrm{i}}$ & $18.50 \pm 1.50^{\mathrm{i}}$ & $160.20 \pm 5.50^{n}$ & $64.10 \pm 1.50^{n}$ \\
\hline & $10^{-3}$ & $30.50 \pm 2.00 \mathrm{~g}$ & $4.20 \pm 0.50 \mathrm{~g}$ & $11.70 \pm 1.00 \mathrm{e}$ & $8.10 \pm 0.50^{\mathrm{f}}$ & $82.30 \pm 2.00^{\mathrm{i}}$ & $32.90 \pm 1.00^{\mathrm{i}}$ \\
\hline & $10^{-2}$ & $7.20 \pm 0.50^{\mathrm{d}}$ & $1.00 \pm 0.10^{d}$ & $5.70 \pm 0.20^{\mathrm{b}}$ & $3.90 \pm 0.20^{c}$ & $40.20 \pm 1.50^{\mathrm{f}}$ & $16.10 \pm 1.00^{\mathrm{f}}$ \\
\hline \multirow{3}{*}{ Syringic acid } & $10^{-5}$ & $193.30 \pm 5.90^{\mathrm{p}}$ & $27.30 \pm 2.00^{n}$ & $45.90 \pm 2.00^{1}$ & $3.20 \pm 0.40^{b}$ & $187.00 \pm 11.00 \mathrm{P}$ & $74.80 \pm 4.00^{p}$ \\
\hline & $10^{-3}$ & $48.20 \pm 2.50 \mathrm{i}$ & $6.80 \pm 0.50^{\mathrm{i}}$ & $45.20 \pm 4.00^{\mathrm{k}}$ & $3.20 \pm 0.20^{b}$ & $42.30 \pm 2.00^{g}$ & $16.90 \pm 1.50 \mathrm{~g}$ \\
\hline & $10^{-2}$ & $4.40 \pm 0.50^{\mathrm{b}}$ & $0.60 \pm 0.01^{\mathrm{a}}$ & $3.70 \pm 0.20^{a}$ & $2.60 \pm 0.10^{\mathrm{a}}$ & $3.80 \pm 0.50^{\mathrm{a}}$ & $1.80 \pm 0.01^{\mathrm{a}}$ \\
\hline \multirow{4}{*}{ Ferulic acid } & $10^{-5}$ & $286.30 \pm 10.50$ & $4.00 \pm 0.50^{\circ}$ & $82.40 \pm 4.00^{n}$ & $56.70 \pm 3.00^{1}$ & $190.00 \pm 10.00 \mathrm{q}$ & $76.00 \pm 4.00 \mathrm{q}$ \\
\hline & $10^{-3}$ & $45.80 \pm 2.00^{h}$ & $6.50 \pm 1.00^{h}$ & $94.70 \pm 5.00 \mathrm{p}$ & $65.20 \pm 2.00 \mathrm{p}$ & $84.20 \pm 3.00^{k}$ & $33.70 \pm 2.00^{k}$ \\
\hline & $10^{-2}$ & $4.10 \pm 0.30^{\mathrm{a}}$ & $0.60 \pm 0.01^{\mathrm{a}}$ & $8.60 \pm 0.50^{c}$ & $5.90 \pm 0.30^{\mathrm{d}}$ & $15.30 \pm 1.50^{c}$ & $6.10 \pm 0.10^{c}$ \\
\hline & $10^{-5}$ & $93.40 \pm 3.50^{1}$ & $13.20 \pm 1.00^{\mathrm{k}}$ & $128.50 \pm 2.00^{\circ}$ & $88.50 \pm 4.00^{\circ}$ & $166.00 \pm 3.00^{\circ}$ & $66.40 \pm 2.00^{\circ}$ \\
\hline \multirow[t]{2}{*}{ Vanillic acid } & $10^{-3}$ & $90.70 \pm 4.50^{\mathrm{k}}$ & $12.80 \pm 1.00^{j}$ & $41.80 \pm 1.00^{j}$ & $28.80 \pm 2.00^{j}$ & $82.00 \pm 2.00^{j}$ & $32.60 \pm 0.20^{j}$ \\
\hline & $10^{-2}$ & $6.20 \pm 1.00^{c}$ & $0.90 \pm 0.10^{c}$ & $10.60 \pm 0.50^{\mathrm{d}}$ & $7.30 \pm 0.50^{\mathrm{e}}$ & $5.40 \pm 0.40^{b}$ & $2.20 \pm 0.10^{b}$ \\
\hline \multirow{3}{*}{$p$-Coumaric acid } & $10^{-5}$ & $95.60 \pm 5.00 \mathrm{~m}$ & $13.50 \pm 1.00^{1}$ & $82.80 \pm 5.00^{n}$ & $57.00 \pm 3.00 \mathrm{~m}$ & $85.50 \pm 3.00^{1}$ & $34.20 \pm 2.00^{1}$ \\
\hline & $10^{-3}$ & $23.20 \pm 2.00^{f}$ & $3.30 \pm 0.50^{f}$ & $14.30 \pm 1.00 \mathrm{~g}$ & $9.90 \pm 0.80 \mathrm{~g}$ & $32.10 \pm 2.00^{\mathrm{e}}$ & $12.80 \pm 1.00 \mathrm{e}$ \\
\hline & $10^{-2}$ & $21.80 \pm 2.00^{\mathrm{e}}$ & $3.10 \pm 0.50^{\mathrm{e}}$ & $13.10 \pm 0.80^{\mathrm{f}}$ & $9.00 \pm 1.00 \mathrm{~g}$ & $20.50 \pm 2.00^{\mathrm{d}}$ & $8.20 \pm 0.50^{d}$ \\
\hline \multirow{3}{*}{$p$-Hydroxybenzoic acid } & $10^{-5}$ & $183.50 \pm 6.80^{\circ}$ & $26.0 \pm 2.50^{n}$ & $87.50 \pm 2.00^{\circ}$ & $60.30 \pm 3.00^{n}$ & $102.30 \pm 6.50 \mathrm{~m}$ & $40.90 \pm 3.00 \mathrm{~m}$ \\
\hline & $10^{-3}$ & $82.20 \pm 3.90^{\mathrm{j}}$ & $11.60 \pm 1.00^{j}$ & $78.70 \pm 3.00 \mathrm{~m}$ & $54.20 \pm 4.00^{\mathrm{k}}$ & $53.50 \pm 2.00^{h}$ & $21.40 \pm 1.50^{h}$ \\
\hline & $10^{-2}$ & $22.60 \pm 2.00^{f}$ & $3.20 \pm 0.50^{\mathrm{e}}$ & $20.00 \pm 1.00^{h}$ & $13.80 \pm 1.00^{\mathrm{h}}$ & $21.30 \pm 1.00^{\mathrm{d}}$ & $8.50 \pm 0.50^{\mathrm{d}}$ \\
\hline Control & - & $707.8 \pm 15.60 \mathrm{q}$ & - & $145.2 \pm 5.00 \mathrm{q}$ & & $250.0 \pm 8.00^{r}$ & \\
\hline
\end{tabular}

Experimental data are expressed as mean \pm standard deviation $(n=3)$. Different small letters indicate a significant difference at $P<0.05$. Data with the same letter in a column are not significantly different, as determined using Duncan's multiple range test. 


\subsection{Autotoxic Effect of Alfalfa Leaf Extracts}

Alfalfa leaf extracts obtained using different fractions and concentrations exerted a significant effect on the alfalfa seed germination rate (Table 4). Most of the tested fractions exerted a concentration-dependent autotoxic effect on seed germination, total seedling weight, and seedling length. Aqueous alfalfa leaf extract fractions $(10 \mathrm{mg} / \mathrm{mL})$ showed the highest autotoxic effect, as indicated by a lower seed germination rate $(50.40 \% \pm 2.00 \%)$ with the lowest seedling total length (TL) and total weight (TW). The $80 \% \mathrm{MeOH}$ extract and organic phase (acid hydrolysis) at a concentration of $10 \mathrm{mg} / \mathrm{mL}$ promoted seed germination, as represented by higher germination percentage $(92.50 \% \pm 4.00 \%$ and $92.50 \% \pm 7.50 \%)$, compared to the control seeds.

Table 4. Effect of various alfalfa leaf extract fractions on alfalfa seed germination.

\begin{tabular}{|c|c|c|c|c|}
\hline Fraction & $\begin{array}{l}\text { Concentration } \\
(\mathrm{mg} / \mathrm{mL})\end{array}$ & $\begin{array}{c}\text { Germination } \\
\text { Percentage (\%) }\end{array}$ & $* \mathrm{TL}(\mathrm{cm})$ & ** TW (mg) \\
\hline Control & & $90.00 \pm 3.50 \mathrm{p}$ & $8.60 \pm 1.00 \mathrm{q}$ & $2.04 \pm 0.01 \mathrm{j}$ \\
\hline \multirow[t]{2}{*}{$80 \% \mathrm{MeOH}$ extract } & 5 & $92.50 \pm 4.00^{r}$ & $8.40 \pm 1.10^{\circ}$ & $2.50 \pm 0.02^{\mathrm{j}}$ \\
\hline & 10 & $68.01 \pm 2.00^{k}$ & $5.70 \pm 0.50^{1}$ & $1.62 \pm 0.01 \mathrm{~g}$ \\
\hline \multirow[t]{2}{*}{ Organic phase (nonpolar compounds) } & 5 & $85.50 \pm 5.00^{\circ}$ & $6.50 \pm 0.40^{\mathrm{m}}$ & $1.79 \pm 0.01^{h}$ \\
\hline & 10 & $65.30 \pm 4.00^{\mathrm{i}}$ & $5.10 \pm 0.30^{h}$ & $1.54 \pm 0.01^{\mathrm{f}}$ \\
\hline \multirow{2}{*}{ Aqueous phase } & 5 & $64.50 \pm 3.90 \mathrm{~g}$ & $4.90 \pm 0.20^{g}$ & $1.29 \pm 0.01^{c}$ \\
\hline & 10 & $50.40 \pm 2.00^{\mathrm{a}}$ & $3.50 \pm 0.11^{\mathrm{a}}$ & $1.01 \pm 0.01^{\mathrm{a}}$ \\
\hline \multirow[t]{2}{*}{ Organic phase (aglycones) } & 5 & $90.10 \pm 3.50 \mathrm{q}$ & $8.30 \pm 1.00^{n}$ & $1.96 \pm 0.02^{\mathrm{i}}$ \\
\hline & 10 & $60.60 \pm 4.59^{f}$ & $4.10 \pm 0.40^{\mathrm{d}}$ & $1.33 \pm 0.01^{\mathrm{d}}$ \\
\hline \multirow[t]{2}{*}{ Aqueous phase (glycosides) } & 5 & $79.50 \pm 5.00^{n}$ & $6.50 \pm 0.60^{\mathrm{m}}$ & $1.58 \pm 0.01^{f}$ \\
\hline & 10 & $76.50 \pm 3.00 \mathrm{~m}$ & $5.60 \pm 0.20^{\mathrm{k}}$ & $1.50 \pm 0.01^{\mathrm{f}}$ \\
\hline \multirow[t]{2}{*}{ Organic phase (alkaline hydrolysis) } & 5 & $79.50 \pm 6.00^{n}$ & $5.30 \pm 0.40^{\mathrm{i}}$ & $1.75 \pm 0.01^{\mathrm{h}}$ \\
\hline & 10 & $53.60 \pm 3.00^{c}$ & $3.60 \pm 0.11^{b}$ & $1.16 \pm 0.01^{b}$ \\
\hline \multirow[t]{2}{*}{ Aqueous phase (alkaline hydrolysis) } & 5 & $65.00 \pm 3.50^{h}$ & $4.90 \pm 0.20 \mathrm{~g}$ & $1.46 \pm 0.01^{\mathrm{e}}$ \\
\hline & 10 & $54.50 \pm 2.50^{d}$ & $3.70 \pm 0.30^{c}$ & $1.25 \pm 0.01^{\mathrm{c}}$ \\
\hline \multirow[t]{2}{*}{ Organic phase (acid hydrolysis) } & 5 & $92.50 \pm 7.50^{r}$ & $8.50 \pm 0.90 \mathrm{p}$ & $2.04 \pm 0.02^{j}$ \\
\hline & 10 & $65.70 \pm 5.00^{j}$ & $4.80 \pm 0.10^{\mathrm{f}}$ & $1.50 \pm 0.01^{\mathrm{f}}$ \\
\hline \multirow[t]{2}{*}{ Aqueous phase (acid hydrolysis) } & 5 & $68.50 \pm 3.50^{1}$ & $5.50 \pm 0.40^{\mathrm{j}}$ & $1.54 \pm 0.01^{\mathrm{f}}$ \\
\hline & 10 & $53.50 \pm 0.05^{b}$ & $4.70 \pm 0.40^{\mathrm{e}}$ & $1.33 \pm 0.01^{\mathrm{d}}$ \\
\hline
\end{tabular}

Experimental data are expressed as mean \pm standard deviation $(n=3)$. Different small letters indicate a significant difference at $P<0.05$. Data with the same letter in a column are not significantly different, as determined using Duncan's multiple range test. * TL, total length; ${ }^{* *} \mathrm{TW}$, total weight.

\subsection{Identification of Major Phenolic Compounds and Autotoxic Effects}

The results show that quercetin $\left(10^{-5} \mathrm{M}\right)$ significantly inhibited alfalfa seed germination $(57.30 \% \pm 2.10 \%)$, seedling length $(4.90 \pm 0.10 \mathrm{~cm})$, and seedling weight $(1.42 \pm 0.2 \mathrm{mg})$ (Table 5). Similarly, rutin exerted a low autotoxic effect on alfalfa seeds, as indicated by higher germination rates $(82.30 \% \pm 2.50 \%)$, seedling lengths $(5.90 \pm 0.20 \mathrm{~cm})$, and seedling weights $(1.69 \pm 0.10 \mathrm{mg})$.

Table 5. Autotoxic effect of HPLC-identified compounds on alfalfa seed germination and seedling growth.

\begin{tabular}{cccc}
\hline Phenolic Compound & $\begin{array}{c}\text { Germination } \\
\text { Percentage (\%) }\end{array}$ & Seedling Length (cm) & Seedling Weight (mg) \\
\hline Salicylic acid & $74.00 \pm 2.00^{\mathrm{c}}$ & $5.40 \pm 0.20^{\mathrm{b}}$ & $1.60 \pm 0.1^{\mathrm{b}}$ \\
Scopoletin & $69.50 \pm 1.50^{\mathrm{b}}$ & $5.60 \pm 0.30^{\mathrm{c}}$ & $1.63 \pm 0.1^{\mathrm{c}}$ \\
Rutin & $82.30 \pm 2.50^{\mathrm{d}}$ & $5.90 \pm 0.20^{\mathrm{d}}$ & $1.69 \pm 0.1^{\mathrm{d}}$ \\
Quercetin & $57.30 \pm 2.10^{\mathrm{a}}$ & $4.90 \pm 0.10^{\mathrm{a}}$ & $1.42 \pm 0.2^{\mathrm{a}}$ \\
Control & $91.30 \pm 1.50^{\mathrm{e}}$ & $8.40 \pm 0.50^{\mathrm{e}}$ & $1.98 \pm 0.1^{\mathrm{e}}$ \\
\hline
\end{tabular}

Experimental data are expressed as mean \pm standard deviation $(n=3)$. Different small letters indicate a significant difference at $P<0.05$. Data with the same letter in a column are not significantly different, as determined using Duncan's multiple range test. 


\subsection{Identification of Major Saponins and Autotoxic Effects}

Autotoxic compounds of alfalfa were analyzed using HPLC methods (Figures 2-4). Its seed germination rate showed a wide variation in the aliquot of different fractions. In this study, seven different saponins were identified from root and leaf extracts: Medicagenic acid; soyasaponin I; 3-Glc-Glc, 28 AraRhaXyl medicagenic acid; 3-Glc, 28-Glc medicagenic acid; 3-Glc, 28 AraRhaXyl medicagenic acid; 3-GlcA, 28 AraRha medicagenic acid; and zanhic acid tridesmoside (Figures 5-7). These saponins were used to test autotoxicity by determining seed germination and seedling growth rates. The results showed that all saponin compounds influenced seed germination (Table 6). Among these, medicagenic acid showed the highest autotoxic effect, as represented by lower seed germination rates $(68.7 \% \pm 3.50 \%)$. No significant differences were found between the autotoxicity rates of 3-Glc, 28-Glc medicagenic acid and 3-GlcA, 28 AraRha medicagenic acid on alfalfa seed germination at a concentration of $500 \mathrm{ppm}$.

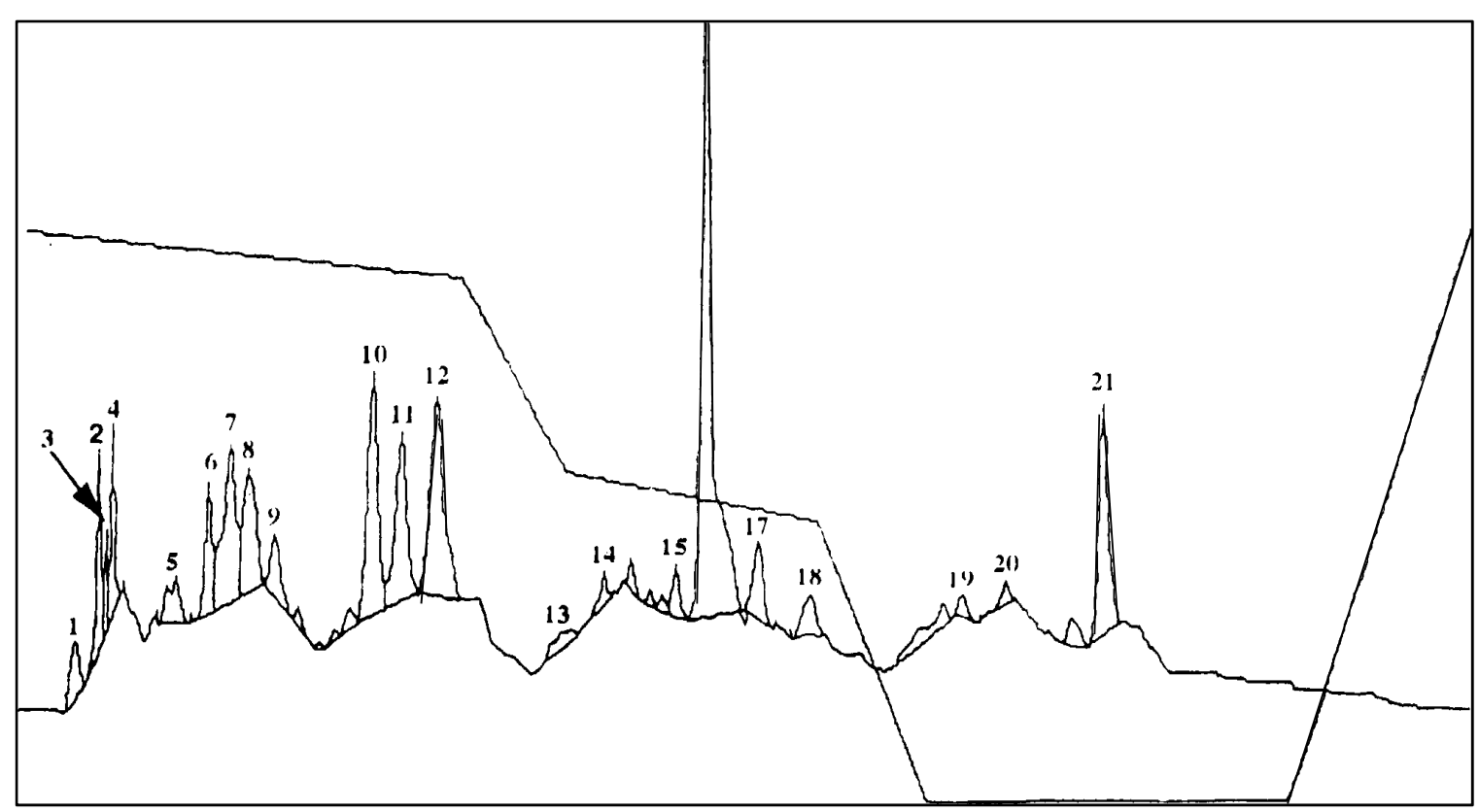

Figure 2. Chromatogram of alfalfa root parts-derived saponins. Peak 10: 3-Glc, 28 AraRhaXyl medicagenic acid (MA); peak 12: 3-Glc, 28-Glc MA; peak 16: 3-GlcA, 28 AraRhaXyl MA; peak 18: soyasaponin I; and peak 21: 3Glc MA. 


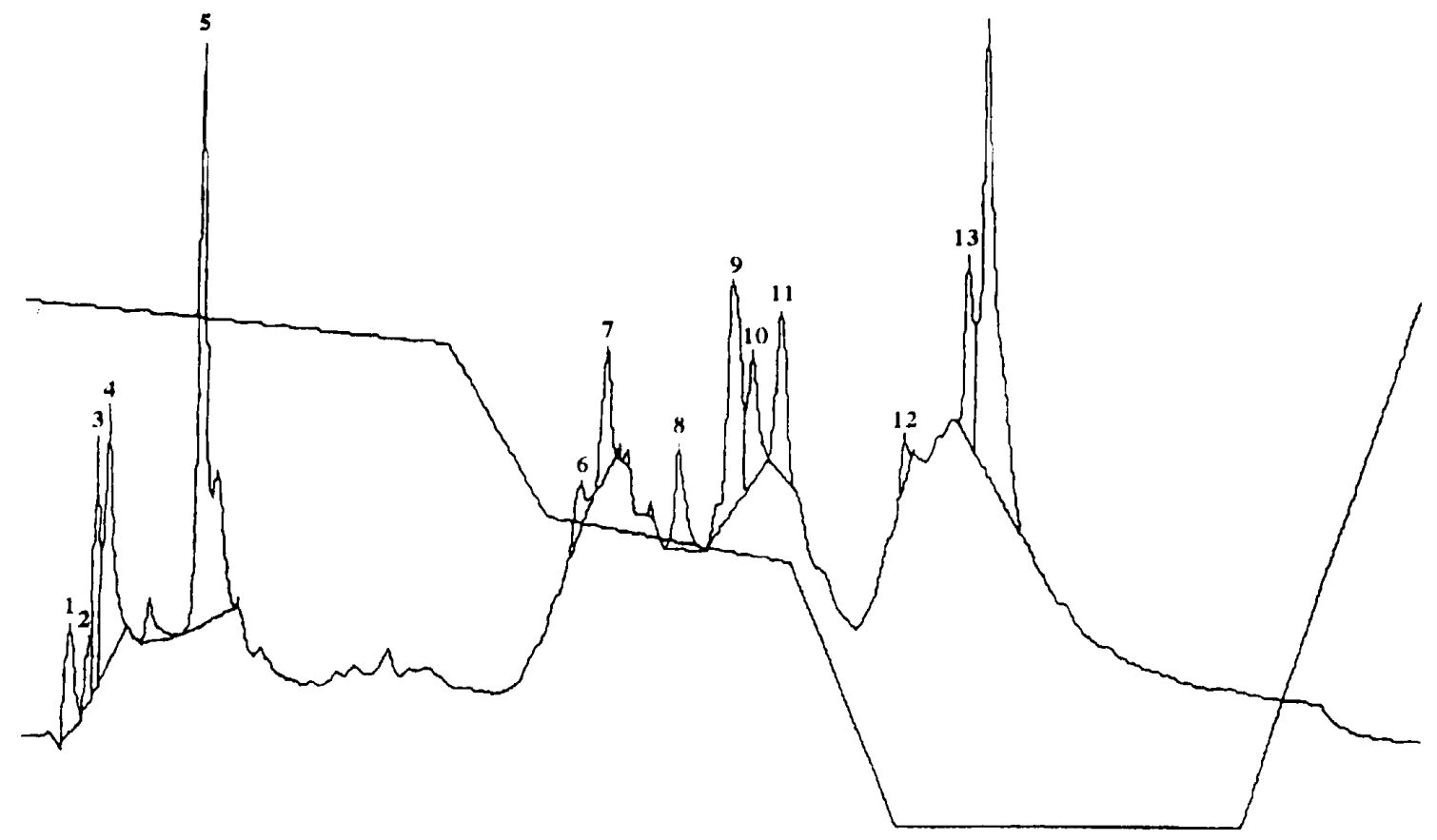

Figure 3. Chromatogram of alfalfa leaf-derived saponins. Peak 8: 3-GlcA, 28 AraRhaXyl medicagenic acid; peak 9: 3-GlcA, 28 AraRha medicagenic acid; and peak 11: Soyasaponin I.

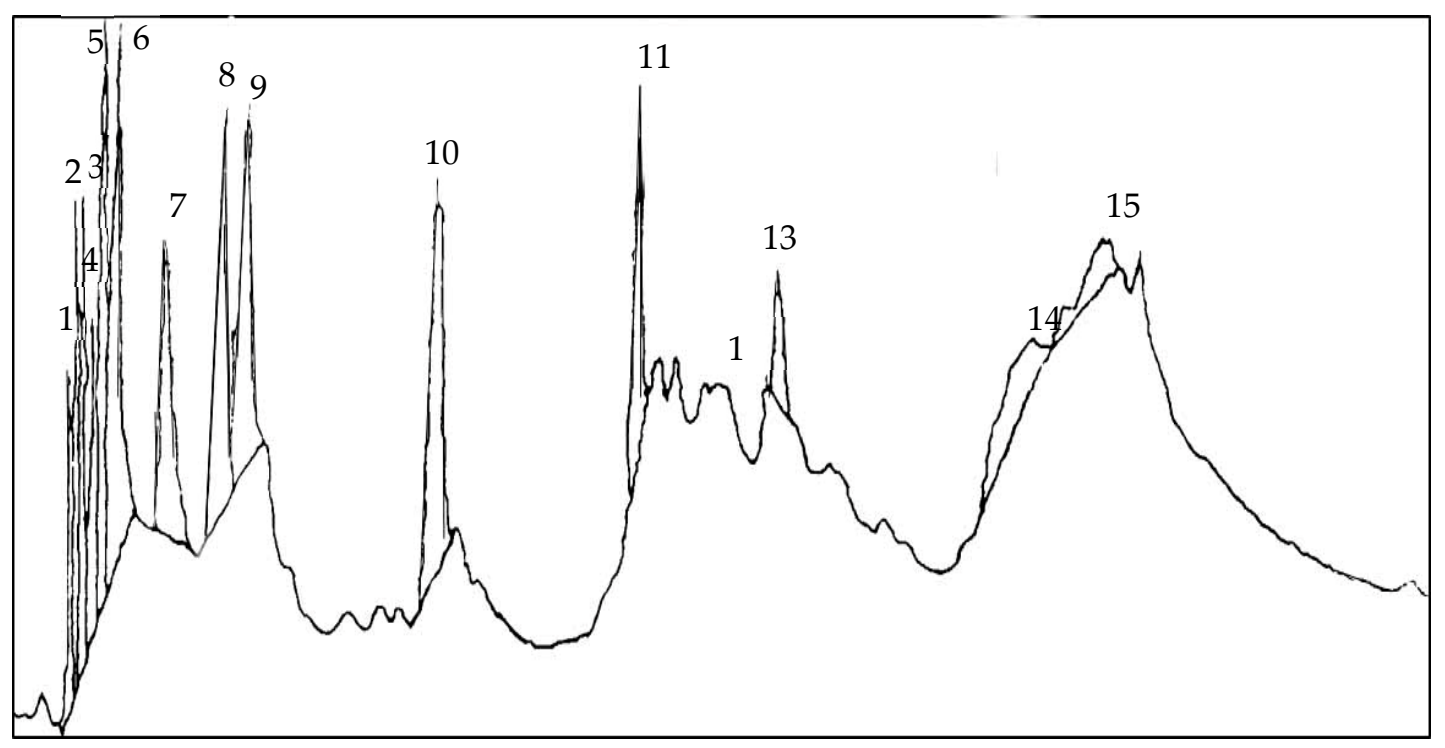

Figure 4. Chromatogram of prosaponin from alkaline hydrolysis of zanhic acid tridesmoside. Peak 11: zanhic acid. 


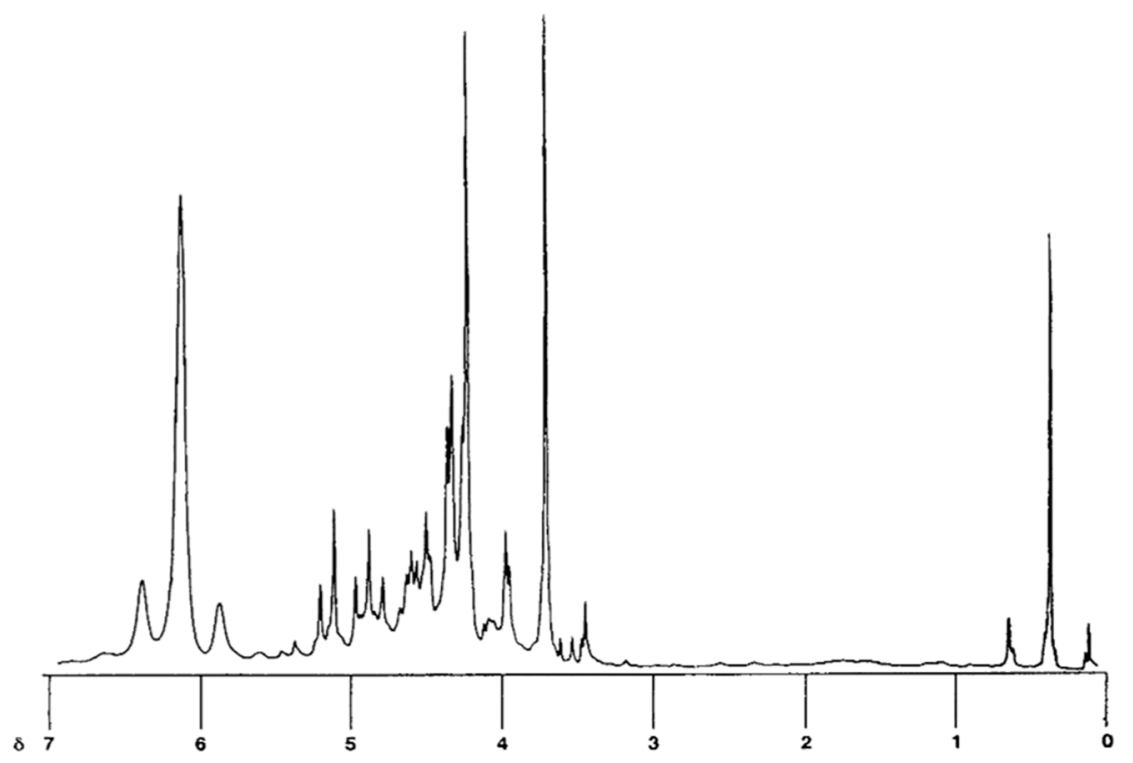

Figure 5. ${ }^{1} \mathrm{H}$ NMR spectrum of alfalfa-derived saponins.

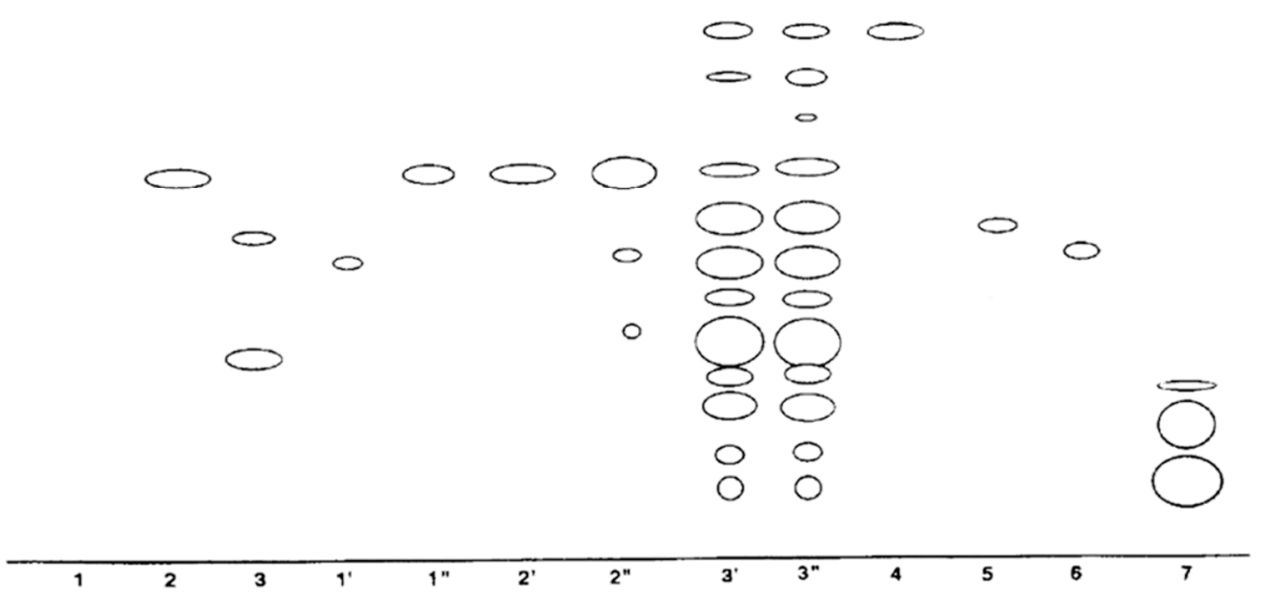

Figure 6. Thin-layer chromatography of crude extracts from alfalfa leaves, stems, and roots under UV light. 1: Medicagenic acid; 2: Soyasaponin 1; 3: 3-Glc-Glc, 28 AraRhaXyl medicagenic acid; 1' and 1": Stem samples; $2^{\prime}$ and 2": Leaf samples; $3^{\prime}$ and $3^{\prime \prime}$ : Root samples; 4: 3-Glc, 28-Glc medicagenic acid; 5: 3-Glc, 28 AraRhaXyl medicagenic acid; 6: 3-GlcA, 28 AraRha medicagenic acid; and 7: Zanhic acid tridesmoside. 


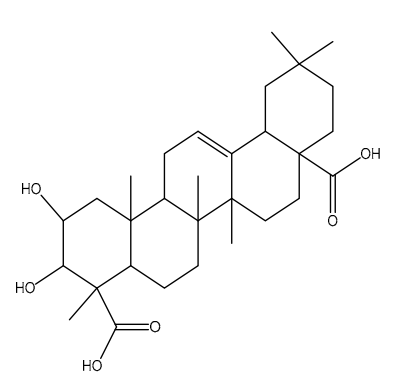

Medicagenic acid

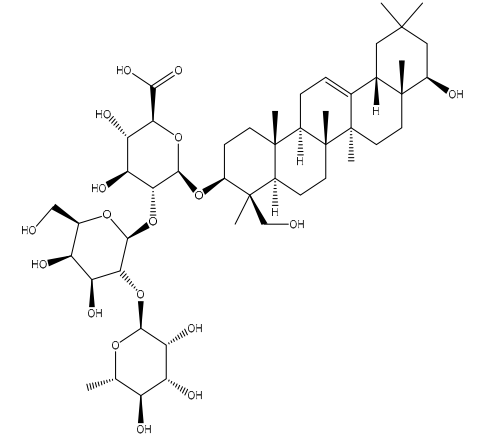

Soyasaponin 1

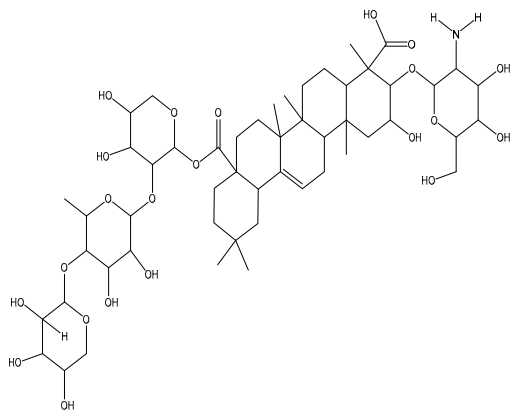

3-GlcA, 28 AraRhaXyl medicagenic acid

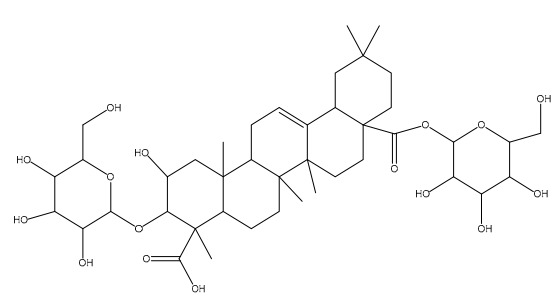

3-Glc 28-Glc medicagenic acid

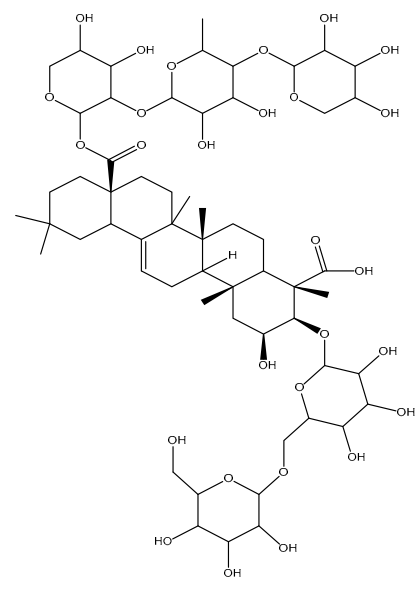

3-Glc-Glc, 28 AraRhaXyl medicagenic acid

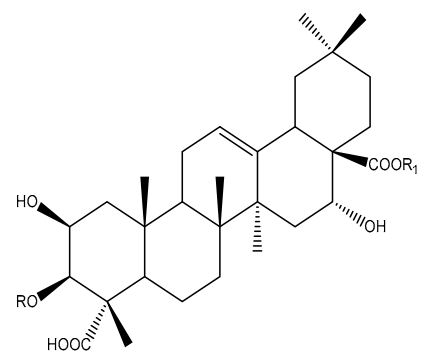

Zanhic acid tridesmoside

Figure 7. Structures of saponins identified in leaf extracts of alfalfa.

Table 6. Identification of saponins in the alfalfa leaf extracts.

\begin{tabular}{ccc}
\hline Saponin & Concentration (ppm) & Germination (\%) \\
\hline Medicagenic acid & 500 & $68.7 \pm 3.50^{\mathrm{b}}$ \\
Soyasaponin I & 500 & $75.6 \pm 6.80^{\mathrm{c}}$ \\
3-Glc-Glc, 28 AraRhaXyl medicagenic acid & 500 & $0^{\mathrm{a}}$ \\
3-Glc, 28-Glc medicagenic acid & 500 & $87.3 \pm 5.50^{\mathrm{e}}$ \\
3-Glc, 28 AraRhaXyl medicagenic acid & 500 & $92.4 \pm 8.90^{\mathrm{f}}$ \\
3-GlcA, 28 AraRha medicagenic acid & 500 & $86.7 \pm 6.50^{\mathrm{e}}$ \\
Zanhic acid tridesmoside & 500 & $85.4 \pm 5.00^{\mathrm{d}}$ \\
\hline
\end{tabular}

Data are expressed as mean \pm standard deviation $(n=3)$. Different small letters indicate a significant difference at $P<0.05$. Data with the same letter in a column are not significantly different, as determined using Duncan's multiple range test.

\subsection{Principal Component Analysis (PCA)}

To assess the correlation between the phenolic compounds and autotoxic properties of alfalfa, the GC data were subjected to PCA. PC1 (vertical axis) accounted for $67.58 \%$ of the total variance, whereas PC2 (horizontal axis) accounted for 32.16\% (Figure 8). PCA showed higher loadings for 3-GlcA, 28 AraRhaXyl medicagenic acid, rutin, salicylic acid, and scopoletin. The direction and length of the arrow indicate the direction and magnitude of each variable's contribution. The angle between the arrows and axis is inversely proportional to the correlation between each variable and the axis constructed in the ordination. The PCA results indicated that the phenolic compounds and saponin composition had significant effects on the variables. In this study, the variables oriented in the same direction were considered more closely related. The PCA analysis distinctly separated the alfalfa leaf extract-derived saponin compounds from the phenolic compounds. It is noteworthy to mention that 
all the variables (phenolic compounds) were located at the positive side (second and third quadrats) of PC1.

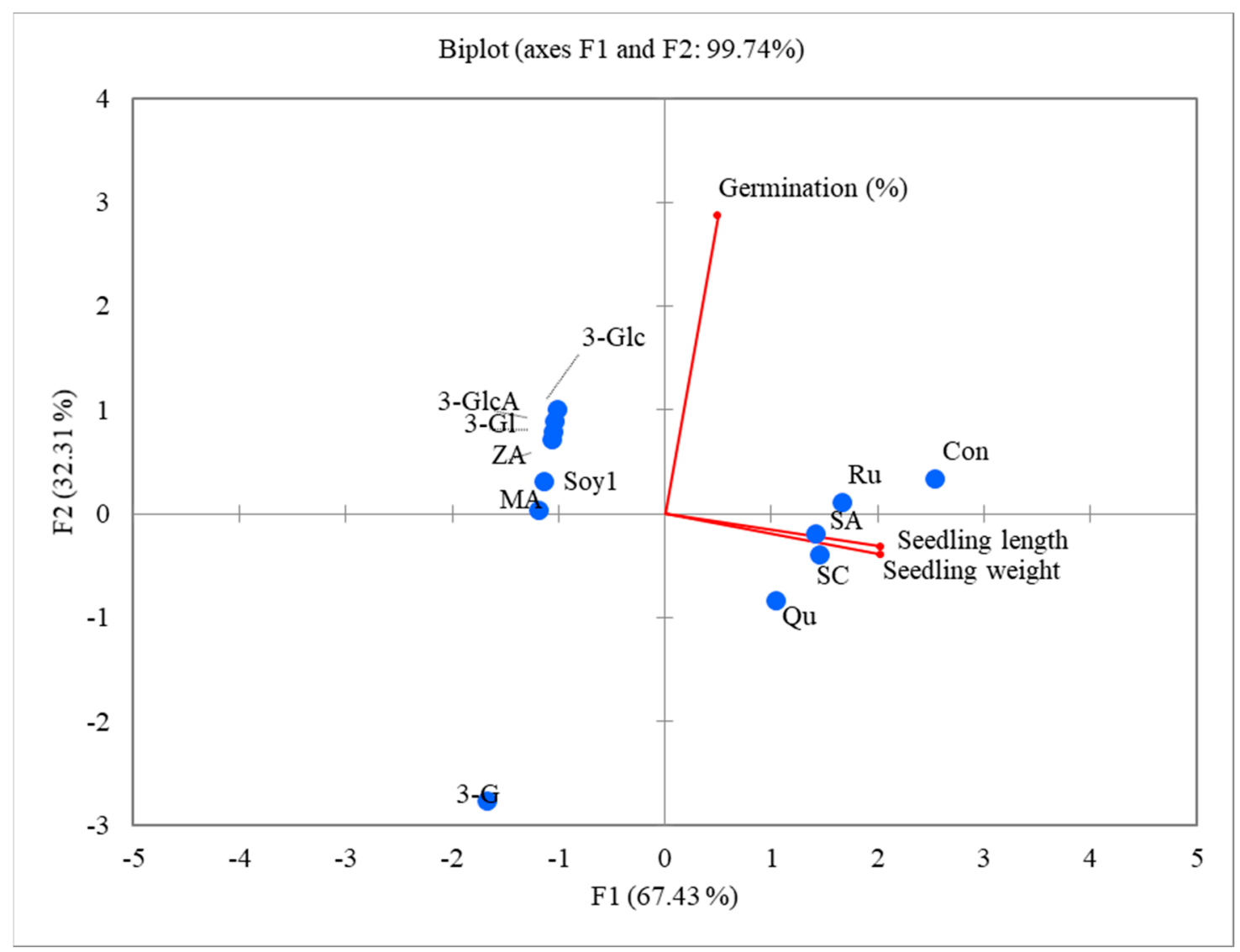

Figure 8. Principal composition analysis (PCA) biplot constructed by plotting the PC1 (vertical axis) scores against the PC2 (horizontal axis) scores obtained from phenolic compounds and saponins. MA: Medicagenic acid; Soy1: Soyasaponin I; 3G: 3-Glc-Glc, 28 AraRhaXyl medicagenic acid; 3-Gl: 3-Glc, 28-Glc medicagenic acid; 3-Glc: 3-Glc, 28 AraRhaXyl medicagenic acid; 3-GlcA: 3-GlcA, 28 AraRha medicagenic acid; ZA: Zanhic acid tridesmoside; Ru: Rutin; SA: Salicylic acid; SC: Scopoletin; Qu: Quercetin; and Con: Control.

\section{Discussion}

In this study, the alfalfa leaf extracts showed a wide range of allelopathic effects on callus growth, seed germination, and seedling growth of various weeds. Callus growth and fresh weight were inversely related to extract concentration. Increasing the extract concentration from 0.1 to $5 \mathrm{mg} / \mathrm{mL}$ had an intense inhibitory effect on the biomass of the calluses of all studied weeds. The growth and development of the callus of C. album was highly sensitive to all the alfalfa extract concentrations, as indicated by smaller biomasses and higher callus growth inhibition rates. The lower alfalfa extract concentration $(0.1 \mathrm{mg} / \mathrm{mL})$ promoted callus growth in $D$. ciliaris. These results indicate that alfalfa leaf extract's allelopathic effect on weeds is species specific. Moreover, some of the phenolic compounds present in alfalfa have been shown to exert both stimulatory and inhibitory effects on calluses [51]. Similar to the report by Braga et al. [52], we showed that higher concentrations of the identified allelochemicals effectively suppressed callus growth and decreased its biomass. In this study, the allelochemicals involved in the allelopathic effect of alfalfa were analyzed using HPLC. The identified phenolic compounds, including salicylic acid, syringic acid, ferulic acid, vanillic acid, $p$-coumaric acid, and $p$-hydroxybenzoic acid, significantly inhibited the callus growth of weeds in a concentration-dependent manner. The inhibitory effects of these compounds on callus biomass 
were observed with the $10^{-5} \mathrm{M}$ alfalfa leaf extracts. Phenolic compounds such as $p$-coumaric acid reportedly inhibit photosynthesis and the enzymatic activities of PG1, CG6PDH, AID, and OPPP, which is detrimental to plant growth [53]. $p$-Coumarin and its derivatives reportedly induce water stress in plants by increasing osmolality and are known for their inhibitory effect on seed germination and plant growth [54]. Additionally, they may also exert a deleterious effect on root growth by altering the morphological and physiological structure of the root [55].

Moreover, some studies have suggested the direct involvement of reactive oxygen species (ROS) in allelopathy. For example, polyphenols are responsible for forming superoxide anions [56] and hydroxyl radicals by donating electrons to molecular oxygen [57], which, in turn, rapidly alters membrane permeability and cellular components such as DNA and proteins. In addition to their antioxidative properties, some phenolic compounds possess phytotoxic properties and cause excessive ROS regeneration, which affects plant growth and development; causes tissues injury, programmed cell death (PCD), and cell membrane disruption; and damages DNA and other biological molecules [58,59]. Some previous studies on the allelopathic properties of phenolic compounds have suggested that their phytotoxicity can have physiological effects such as the reduction of the activity of enzymes involved in ATP synthesis during photosynthesis [60-62]. Furthermore, these compounds may also possess the ability to alter mineral transportation and stomatal regulation in plants [63,64]. Moreover, an inhibitory effect of allelochemicals was attributed to their ability to deform the chloroplasts and mitochondria [62].

In order to assess autotoxicity, the inhibitory effect of the isolated saponins was studied in terms of alfalfa seed germination and visible seedling growth. The results indicated that alfalfa-derived saponins exert a wide range of inhibitory effects on alfalfa seed germination. It has been argued that the differences in the structures of the saponins may result in differences in their biological activities [65]. Moreover, the allelopathic potential of these compounds largely depends on the sugar groups attached to the aglycone and on the cultivars used [66,67]. The treated alfalfa seedlings experienced lack of root hairs, reduced seedling taproots, and complete root color loss. Amongst the isolated saponins, medicagenic acid most effectively suppressed alfalfa seedling growth, indicating that it is partially responsible for the autotoxic effect on alfalfa seedlings. Moreover, the autotoxic effects of zanhic acid glycosides and sapogenin salt have been reported by Oleszek and Jurzysta [66], who suggested that these effects are highly dependent on their concentration and structure [68]. Mung bean-derived soyasaponin I reportedly exerts a higher inhibitory effect on weed seedling elongation and root growth [69]. Moreover, although related, the other saponins (including medicagenic acid and monodesmosides) are more active than bidesmosides [59,70].

In this study, the presence of these compounds in the growing medium affected seed germination and seedling growth rates. Treatment of growing seedlings with saponins can cause structural changes in the cell membrane and cell wall swelling as well as alter the $\mathrm{O}_{2}$ permeability of the cell membrane, which ultimately decreases seedling growth [68]. Treatment with saponin has also been shown to alter water absorption at the lipid bilayer interface [71] and may affect cellulose synthesis [72]. High concentrations of quercetin and rutin have been shown to inhibit the seed germination of various plant species by impairing respiration and ATP levels in embryogenic cells via substrate oxidation or phosphate uptake inhibition, which may uncouple oxidative phosphorylation [73,74]. Additionally, treatment with rutin was shown to drastically reduce the protein content of Arabidopsis cells [75]. Zanhic acid, medicagenic acid, and soyasaponin reportedly caused browning of the meristematic area of seedling roots [70] and inhibited b-1,4-glucan synthesis, which is responsible for cellulose synthesis $[72,76]$. Although the synergistic activity of phenolic compounds and saponins was not investigated in the present study, it was reportedly observed in Spodoptera littoralis [77].

Studies showed that saponins present in the extracts of alfalfa are toxic to weeds and insects [78-80]. Medicagenic acid is the most effective allelochemical responsible for allelopathic potential of alfalfa. This compound is associated with reduction of insect activity and induced very high mortality in Acyrthosiphon pisum [81,82]. In another study, derivatives of medicagenic acids obtained from leaves 
extracts of alfalfa caused inhibition of plant growth of Amaranthus, Lepidium, and Lycopersicon sp. [83]. Moreover, other saponins such as zanhic acid tridesmoside, 3-GlcA, 28 AraRhaXyl medicagenic acid glycoside, and 3-GlcA, 28 AraRha medicagenic acid glycoside identified from alfalfa inhibited the reproduction and survival rate of aphids [78,84]. In a similar study, 3GlcA, 28 AraRhaXyl medicagenic acid obtained from the alfalfa extracts inhibited the larval growth and development of Ostrinia nubilalis, Tenebrio molitor, suppressed the growth of Trichoderma viride [79]. Data from the present study showed that alfalfa extracts with a high concentration of allelocompounds including phenolics, flavonoids, and saponins can provide valuable source of raw materials for the development of potential bioherbicides for weed control.

\section{Materials and Methods}

\subsection{Chemicals}

All chemicals and solvents used were of analytical grade and supplied by commercial providers. Methanol was obtained from J.T. Baker Chemical Co. (Phillipsburg, NJ, USA). Standards for phenolic compound and saponin estimation were purchased from Sigma-Aldrich Corp. (St. Louis, MO, USA).

\subsection{Plant Materials}

Seeds of the various weeds and alfalfa plants used in this study were kindly supplied by the Department of Applied Plant Science, Kangwon National University, South Korea.

\subsection{Callus Regeneration and Subculture}

Seeds of $C$. album, A. lividus, D. ciliaris, P. oleracea, and C. communis were sterilized with sodium hypochlorite ( $6 \%$ ) for $30 \mathrm{~min}$, rinsed by distilled water $\geq 6$ times, dried using sterilized paper towels for $1 \mathrm{~h}$, and then allowed to germinate in MS medium. Young leaves of in vitro grown plantlets of C. album, A. lividus, D. ciliaris, P. oleracea, and C. communis were used for callus induction, using full strength Murashige and Skoog (MS) medium. MS medium was prepared by mixing 3\% $(w / v)$ sucrose supplemented with $1 \mathrm{mg} \mathrm{L}^{-1}$ 2,4-dichloroohenoxyacetic acid (2,4-D). The $\mathrm{pH}$ of the medium was adjusted to 5.8 using $\mathrm{I} \mathrm{N} \mathrm{NaOH}$ and $\mathrm{HCl}$. This medium was gelled using $0.8 \%$ plant agar before autoclaving at $1.1 \mathrm{~kg} \mathrm{~cm}^{-2}$ for $15 \mathrm{~min}$. Sterilized medium $(20 \mathrm{~mL})$ was dispensed into each Petri dish $(10 \times 15 \mathrm{~cm})$ and used for inducing calluses. Young leaves from the in vitro grown plants were cut across the midrib and immediately placed in the callus-induction medium. Regenerated calluses were proliferated further by subculturing every week in the MS medium supplemented with $1 \mathrm{mg} \mathrm{L}^{-1} 2,4-\mathrm{D}$.

\subsection{Evaluation of Allelopathic Effects of Plant Extracts on Callus Growth}

Calluses induced in the leaf section of different weeds were cultured in MS medium supplemented with $1 \mathrm{mg} \mathrm{L}^{-1}$ 2,4-D. Fresh and healthy callus $(50 \mathrm{mg})$ from each plant sample were soaked in different alfalfa leaf extract concentrations $(0.1 \%, 5 \%$, and $10 \% w / v)$. Six to eight calluses were grown in each Petri dish containing MS medium supplemented with $1 \mathrm{mg} \mathrm{L}^{-1} 2,4-\mathrm{D}$ and plant extracts. The Petri dishes were allowed to grow in a culture room for four weeks and three replications were maintained for each treatment. For the control treatment, the plant extracts were replaced with distilled water.

\subsection{Effect of Allelopathic Compounds on Callus Growth}

To assess the effect of allelopathic compounds on growth, the identified phenolic compounds, including salicylic acid, $p$-coumaric acid, vanillic acid, $p$-hydroxybenzoic acid, ferulic acid, and syringic acid at concentrations of $10^{-2}, 10^{-3}$, and $10^{-5} \mathrm{M}$, were prepared. They were then mixed with MS medium supplemented with $1 \mathrm{mg} \mathrm{L}^{-1} 2,4-\mathrm{D}$, upon which six to eight young and fresh calluses were placed and maintained at $25 \pm 1^{\circ} \mathrm{C}$ for $40 \mathrm{~d}$. The callus fresh weight was recorded after $40 \mathrm{~d}$. 


\subsection{Autotoxic Effect of Alfalfa Leaf Extracts}

Alfalfa seeds were sterilized using sodium hypochlorite $(6 \%)$ for $30 \mathrm{~min}$, rinsed with distilled water $\geq 6$ times, and then dried using sterilized paper towels for $1 \mathrm{~h}$. A sterilized filter paper containing 100 seeds was placed in a Petri dish and $20 \mathrm{~mL}$ of different concentrations of phenolic compound solution was added, while the same amount of distilled water was used for the control. Treated seeds were transferred to the growth chamber at $25 \pm 1{ }^{\circ} \mathrm{C}$, and the germination percentage of each species was determined weekly. The fresh weight of the germinated seedlings was also recorded. The seedlings were then oven dried at $60^{\circ} \mathrm{C}$ for $5 \mathrm{~h}$, and their dry weight recorded.

$$
\text { Percentage inhibition }(\%)=1-(\text { plant extracts/control }) \times 100 \text {. }
$$

\subsection{Preparation of Plant Extracts}

To assess the composition and concentration of its allelochemical compounds, alfalfa leaves were collected from the experimental field of Kangwon National University (South Korea) in 2014, 2015, and 2016. The collected leaves samples were dried at room temperature $\left(25^{\circ} \mathrm{C}\right)$ for $24 \mathrm{~h}$. Then, $10 \mathrm{~g}$ of the ground, dried powder samples of each plant were each dissolved in $80 \%$ ethanol, using a $100-\mathrm{mL}$ conical flask with continuous shaking $(40 \mathrm{rpm})$ at room temperature for $20 \mathrm{~h}$. The solutions were then filtered using Whatman No. 1 filter paper for debris removal. The obtained filtrates were evaporated to dryness in a rotary evaporator (Eyela, SB-1300, Shanghai Eyela Co. Ltd.) at $42{ }^{\circ} \mathrm{C}$. The dry filtrate residues were then re-dissolved in $80 \%$ HPLC-grade ethanol $(0.01 \mathrm{~mL})$ for phenolic compound analysis using HPLC.

\subsection{Phenolic Compound Identification and Quantification Using HPLC}

The identification and quantification of phenolic compounds from different accessions were carried out using HPLC, as previously described [85]. Briefly, $1 \mathrm{~g}$ of each dried seed sample was crushed to powder, extracted with $10 \mathrm{~mL}$ of $80 \%$ methanol, and shaken in an orbital shaker for $24 \mathrm{~h}$ at room temperature. To remove debris, all sample solutions were filtered using a Whatman No. 1 filter paper. The extracted solvent $\left(80 \%\right.$ methanol) was then evaporated at $40{ }^{\circ} \mathrm{C}$ using a vacuum rotary evaporator. The dried extract was dissolved in $80 \%$ methanol $(10 \mathrm{~mL})$ to obtain a $50 \mu \mathrm{g} / \mathrm{mL}$ solution, passed through a $0.45 \mu \mathrm{m}$ filter unit (TITAN syringe filter nylon membrane), and then injected into the HPLC system. Quantification of individual phenolic compounds in each sample was performed using the HPLC system from Shimadzu Corporation (Kyoto, Japan), equipped with two LC-10AD VP pumps and a SPD-M10A VP photodiode array detector $(280 \mathrm{~nm})$. The YMC-Pack ODS-AM-303 column ( $4.6 \mathrm{~mm}$ id $\times 250 \mathrm{~mm}, 5 \mu \mathrm{m}$ particle size) was used for chromatographic separation of phenolic compounds. The injection volume, flow rate, and detection wavelength were $20 \mu \mathrm{L}, 1 \mathrm{~mL} \mathrm{~min}^{-1}$, and $280 \mathrm{~nm}$, respectively. The mobile phase consisted of solvent A ( $0.1 \%$ glacial acetic acid adjusted with water) and solvent $B(0.1 \%$ glacial acetic acid in acetonitrile). Gradient elution was as follows: Solvent B was elevated from $8 \%$ to $10 \%$ B ( $2 \mathrm{~min}$ ), $10-30 \%$ B ( $27 \mathrm{~min}$ ), 30-90\% B (50 min), 90-100\% B (52 min), and then held at $100 \%$ of $B(57 \mathrm{~min})$. Phenolic compound calibration curves were obtained using different concentrations (10,50, and 100 ppm) of standard compounds. Polyphenols were identified and quantified by matching their retention times with those of authentic phenolic compound standards.

\subsection{Identification of Major Saponins in Alfalfa Leaves}

Fresh young alfalfa leaves were harvested, dried, and ground at room temperature. Approximately $2 \mathrm{~g}$ of the powdered sample was boiled in $50 \mathrm{~mL}$ of methanol-distilled water (4:1) for $6 \mathrm{~h}$. To remove debris, all the sample solutions were filtered through Whatman No. 1 filter paper. The extracted solvent $\left(80 \%\right.$ methanol) was evaporated at $40{ }^{\circ} \mathrm{C}$ in a vacuum rotary evaporator. The extract was dissolved in ether to precipitate the saponins, at room temperature. The obtained solution was centrifuged at $4{ }^{\circ} \mathrm{C}$ for $20 \mathrm{~min}$. Purification of saponins in the precipitate sample was performed as 
previously described [86]. Briefly, $10 \mathrm{~g}$ of crude saponin samples were suspended in $100 \mathrm{~mL} \mathrm{CHCl}$. Thin layer chromatography (TLC) was performed to visualize the patterns of unknown compounds. After repeated chromatography, compound identification in the samples was performed using NMR analysis.

\subsection{Nuclear Magnetic Resonance (NMR) Spectroscopic Analyses}

For structural analysis, ${ }^{1} \mathrm{H}$ and ${ }^{13} \mathrm{C}$ spectra were measure on an NMR spectrometer Varian Unity (Varian Inc., Palo Alto, CA, USA), $300 \mathrm{MHz}$, d6-DMSO, with tetramethylsilane (TMS) as an internal standard. Deuterated chloroform $\left(\mathrm{CDCl}_{3}\right)$ was used as the solvent.

\subsection{Statistical Analyses}

Each experiment was performed in triplicate, and the data are expressed as mean \pm standard deviation. Quantitative data were statistically analyzed using one-way analysis of variance (ANOVA). Significant differences between the obtained data were determined using Duncan's multiple range tests, with $p<0.05$ implying statistical significance. All statistical analyses were performed using SPSS v20.0 from SPSS Inc. (Chicago, IL, USA). Correlated variables were identified using Pearson's correlation coefficient. The principal component analysis (PCA) of quantitative morphological traits was also performed using SPSS software v20.0.

\section{Conclusions}

In conclusion, callus growth in the weed species was highly sensitive to the alfalfa leaf extracts-derived allelopathic phytochemicals. Additionally, all identified saponins possessed autotoxic properties, with the autotoxicity of medicagenic acid being the most potent. Moreover, the significant positive correlation between seed germination rate and phenolic compound concentration indicates that these compounds have a higher inhibitory effect on callus induction and postemergence of weeds and can be potentially developed as bioherbicides for organic farming, which will help conserve biodiversity and the environment.

Author Contributions: B.K.G. performed the experiments and wrote the manuscript. C.Y.Y. supervised the experiments. B.G. and I.-M.C. analyzed the phenolic compounds and edited the manuscript.

Funding: This research received no external funding.

Acknowledgments: This work was supported by funding from the KU research professor program.

Conflicts of Interest: The authors declare no conflict of interest.

\section{References}

1. Griepentrog, H.W.; Dedousis, A.P. Mechanical Weed Control, Soil Engineering; Springer: New York, NY, USA, 2010; pp. 171-179.

2. Bergin, D. Weed Control Options for Coastal Sand Dunes: A Review; New Zealand Forest Research Institute Limited: Rotorua, New Zealand, 2011; pp. 5-13.

3. Rueda-Ayala, V.; Rasmussen, J.; Gerhards, R.; Fournaise, N.E. The influence of post-emergence weed harrowing on selectivity, crop recovery and crop yield in different growth stages of winter wheat. Weed Res. 2011, 51, 478-488. [CrossRef]

4. Zhang, Z.P. Development of chemical weed control and integrated weed management in China. Weed Biol. Manag. 2003, 3, 197-203. [CrossRef]

5. Bond, W.; Grundy, A. Non-chemical weed management in organic farming systems. Weed Res. 2001, 41, 383-405. [CrossRef]

6. Carballido, J.; Rodríguez-Lizana, A.; Agüera, J.; Perez-Ruiz, M. Field sprayer for inter and intra-row weed control: Performance and labor savings. Span. J. Agric. Res. 2013, 11, 642-651. [CrossRef]

7. Gianessi, L.P. The increasing importance of herbicides in worldwide crop production. Pest Manag. Sci. 2013, 69, 1099-1105. [CrossRef] [PubMed] 
8. Mesnage, R.; Arno, M.; Costanzo, M.; Malatesta, M.; Séralini, G.E.; Antoniou, M.N. Transcriptome profile analysis reflects rat liver and kidney damage following chronic ultra-low dose Roundup exposure. J. Environ. Health 2015, 14, 70. [CrossRef] [PubMed]

9. Swanson, N.L.; Leu, A.; Abrahamson, J.; Wallet, B. Genetically engineered crops, glyphosate and the deterioration of health in the United States of America. J. Org. Syst. 2014, 9, 6-37.

10. Colovic, M.B.; Krstic, D.Z.; Lazarevic-Pašti, T.D.; Bondžic, A.M.; Vasic, V.M. Acetylcholinesterase inhibitors: Pharmacology and toxicology. Curr. Neuropharmacol. 2013, 11, 315-335. [CrossRef]

11. Cattani, D.; Acordi Cesconetto, P.; Kruger Tavares, M.; Parisotto, E.B.; De Oliveira, P.A.; Heinz Rieg, C.E.; Concli Leite, M.; Schröder Prediger, R.D.; Wendt, N.C.; Razzera, G.; et al. Developmental exposure to glyphosate-based herbicide and depressive-like behavior in adult offspring: Implication of glutamate excitotoxicity and oxidative stress. Toxicology 2017, 387, 67-80. [CrossRef]

12. Fluegge, K.; Fluegge, K. Glyphosate use predicts healthcare utilization for ADHD in the healthcare cost and utilization project net (HCUPnet): A two-way fixed-effects analysis. Pol. J. Environ. Stud. 2016, 25, 1489-1503. [CrossRef]

13. Fortes, C.; Mastroeni, S.; Segatto, M.M.; Hohmann, C.; Miligi, L.; Bakos, L.; Bonamigo, R. Occupational exposure to pesticides with occupational sun exposure increases the risk for cutaneous melanoma. J. Occup. Environ. Med. 2016, 58, 370-375. [CrossRef] [PubMed]

14. Jayasumana, C.; Gunatilake, S.; Senanayake, P. Glyphosate, hard water, and nephrotoxic metals: Are they the culprits behind the epidemic of chronic kidney disease of unknown etiology in Sri Lanka? Int. J. Environ. Res. Public Health 2014, 11, 2125-2147. [CrossRef] [PubMed]

15. Bhardwaj, T.; Sharma, J.P. Impact of pesticides application in agricultural industry: An Indian scenario. Int. J. Agric. Food Sci. Technol. 2013, 4, 817-822.

16. Baziar, M.R.; Farahvash, F.; Mirshekari, B.; Rashidi, V. Allelopathic effect of rye grass (Lolium persicum) and wild mustard (Sinapis arvensis) on barley. Pak. J. Bot. 2014, 46, 2069-2075.

17. Sitthinoi, P.; Lertmongkol, S.; Chanprasert, W.; Vajrodaya, S. Allelopathic effects of jungle rice (Echinochloa colona (L.) Link) extract on seed germination and seedling growth of rice. Agric. Nat. Resour. 2017, 51, 74-78. [CrossRef]

18. Dayan, F.E.; Cantrell, C.L.; Duke, S.O. Natural products in crop protection. Bioorg. Med. Chem. 2009, 17, 4022-4034. [CrossRef]

19. Dorota, S.; Urszula, K. Allelochemicals as bioherbicides-Present and perspectives. Herbic. Curr. Res. Case Stud. Use 2013, 517-542. [CrossRef]

20. Vyvyan, W.R. Allelochemicals as leads for new herbicides and agrochemicals. Tetrahedron 2002, 58, 1632-1646. [CrossRef]

21. Wang, P.; Zhang, X.; Kong, C. The response of allelopathic rice growth and microbial feedback to barnyard grass infestation in a paddy field experiment. Eur. J. Soil Biol. 2013, 56, 26-32. [CrossRef]

22. Zeng, R.S. Allelopathy-the solution is indirect. J. Chem. Ecol. 2014, 40, 515-516. [CrossRef] [PubMed]

23. Qasem, J.R.; Foy, C.L. Weed allelopathy, its ecological impacts and future prospects: A review. J. Crop. Prod. 2001, 4, 43-92. [CrossRef]

24. Bertin, C.; Yang, X.; Weston, L.A. The role of root exudates and allelochemicals in the rhizosphere. Plant Soil 2003, 256, 67-83. [CrossRef]

25. Klironomos, J.N. Feedback with soil biota contributes to plant rarity and invasiveness in communities. Nature 2002, 417, 67-70. [CrossRef] [PubMed]

26. Callaway, R.M.; Ridenour, W.M. Novel weapons: Invasive success and the evolution of increased competitive ability. Front. Ecol. Environ. 2004, 2, 436-443. [CrossRef]

27. Alias, J.C.; Sosa, T.; Escudero, J.C.; Chaves, N. Autotoxicity against germination and seedling emergence in Cistus ladanifer L. Plant Soil. 2006, 282, 327-332. [CrossRef]

28. Duke, S.O. Proving Allelopathy in Crop-Weed Interactions. Weed Sci. Spec. Issue 2015, 63, 121-132. [CrossRef]

29. Cheng, F.; Cheng, Z. Research progress on the use of plant allelopathy in agriculture and the physiological and ecological mechanisms of allelopathy. Front. Plant Sci. 2015, 6, 1020. [CrossRef] [PubMed]

30. Sangeetha, C.; Baskar, P. Allelopathy in weed management: A critical review. Afr. J. Agric. Res. 2015, 10, 1004-1015. 
31. Cseke, L.J.; Kaufman, P.B. Regulation of metabolite synthesis in plants. In Natural Products from Plants; Cseke, L.J., Kirakosyan, A., Kaufman, P.B., Warber, S., Duke, J.A., Brielmann, H., Eds.; CRC Press: Boca Raton, FL, USA, 2006; pp. 101-141.

32. Einhellig, F.A. Interactions involving allelopathy in cropping systems. Agron. J. 1996, 88, 886-893. [CrossRef]

33. Pramanik, M.H.R.; Nagal, M.; Asao, M.; Matsui, Y. Effect of temperature and photoperiod on phytotoxic root exudates of cucumber (Cucumis sativus) in hydroponic culture. J. Chem. Ecol. 2000, 26, 1953-1967. [CrossRef]

34. Weston, L.A.I. Root exudation: An overview. In Root Ecology. Ecological Studies (Analysis and Synthesis); de Kroon, H., Visser, E.J.W., Eds.; Springer: Heidelberg, Germany, 2003; Volume 168, pp. 235-255.

35. Xuan, T.D.; Tsuzuki, E.; Terao, H.; Matsuo, M.; Khanh, T.D. Identification of potential allelochemicals in kava (Piper methysticum L.) root. Allelopath. J. 2003, 12, 197-204.

36. Li, Z.H.; Wang, Q.; Ruan, X.; Pan, C.D.; Jiang, D.A. Phenolics and Plant Allelopathy. Molecules 2010, 15, 8933-8952. [CrossRef] [PubMed]

37. Blum, U.; Shafer, S.R.; Lehman, M.E. Evidence for inhibitory allelopathic interactions involving phenolic acids in field soils: Concepts vs. an experimental model. Crit. Rev. Plant Sci. 1999, 18, 673-693. [CrossRef]

38. Belz, R.G. Allelopathy in crop/weed interactions-an update. Pest. Manag. Sci. 2007, 63, 308-326. [CrossRef] [PubMed]

39. Tabaglio, V.; Gavazzi, C.; Schulz, M.; Marocco, A. Alternative weed control using the allelopathic effect of natural benzoxazinoids from rye mulch. Agron. Sustain. Dev. 2008, 28, 397-401. [CrossRef]

40. Rasmussen, J.A.; Einhellig, F.A. Synergistic inhibitory effects of p-coumaric and ferulic acids on germination and growth of grain sorghum. J. Chem. Ecol. 1977, 3, 197-205. [CrossRef]

41. Graham, P.H.; Vance, C.P. Legumes: Importance and Constraints to Greater Use. Plant Physiol. 2003, 131, 872-877. [CrossRef] [PubMed]

42. Firdaous, L.; Dhulster, P.; Amiot, J.; Gaudreau, A.; Lecouturier, D.; Kapel, R.; Lutin, F.; Vezina, L.-P.; Bazinet, L. Concentration and selective separation of bioactive peptides from an alfalfa white protein hydrolysate by electrodialysis with ultrafiltration membranes. J. Membr. Sci. 2009, 329, 60-67. [CrossRef]

43. Lamsal, B.P.; Koegel, R.G.; Gunasekaran, S. Some physicochemical and functional properties of alfalfa soluble leaf proteins. LWT-Food Sci. Technol. 2007, 40, 1520-1526. [CrossRef]

44. Ullah, F.; Ahmad, S.; Wahab, S.; Zeb, A.; Khattak, M.K.; Khan, S.; Kang, M. Quality Evaluation of Biscuits Supplemented with Alfalfa Seed Flour. Foods 2016, 5, 68. [CrossRef]

45. Hawkins, C.; Yu, L.X. Recent progress in alfalfa (Medicago sativa L.) genomics and genomic selection. Crop. J. 2018, 6, 565-575. [CrossRef]

46. Kechang, L.; Ping, Z.; Cash, D. Biology and management of major alfalfa diseases and pests. In Alfalfa Management Guide for Ningxia; Cash, D., Yuegao, H., Kechang, L., Suqin, W., Ping, Z., Rong, G., Eds.; China Agricultural Press: Beijing, China, 2009; pp. 37-62.

47. Mölgaard, J.; von Schenck, H.; Olsson, A.G. Alfalfa seeds lower low density lipoprotein cholesterol and apolipoprotein B concentrations in patients with type II hyperlipoproteinemia. Atherosclerosis 1987, 65, 173-179. [CrossRef]

48. Dornbos, D.L., Jr.; Spencer, G.F. Natural products phytotoxicity. A bioassay suitable for small quantities of slightly water soluble compounds. J. Chem. Ecol. 1990, 16, 339-351. [CrossRef] [PubMed]

49. Márton, M.; Mándoki, Z.S.; Csapó, J. Evaluation of biological value of sprouts I. F at content, fatty acid composition. Acta Univ. Sapientiae Aliment. 2010, 3, 53-65.

50. Plaza, L.; de Ancos, B.; Cano, M.P. Nutritional and health-related compounds in sprouts and seeds of soybean (Glycine max), wheat (Triticum aestivum.L) and alfalfa (Medicago sativa) treated by a new drying method. Eur. Food Res. Technol. 2003, 216, 138-144. [CrossRef]

51. Compton, M.E.; Preece, J.E. Response of tobacco callus to shoot tip exudation from five species. HortScience 1988, 23, 208-210.

52. Braga, K.Q.; Coimbra, M.C.; Castro, A.H.F. In vitro germination, callus induction and phenolic compounds contents from Pyrostegia venusta (Ker Gawl.) Miers. Acta Sci. Biol. Sci. 2015, 37, 151-158. [CrossRef]

53. Muscolo, A.; Panuccio, M.R.; Sidari, M. The effect of phenols on respiratory enzymes in seed germination respiratory enzyme activities during germination of Pinus laricio seeds treated with phenols extracted from different forest soils. Plant Growth Regul. 2001, 35, 31-35. [CrossRef] 
54. Gavaghan, C.L.; Li, J.V.; Hadfield, S.T.; Hole, S.; Nicholson, J.K.; Wilson, I.D.; Howe, P.W.A.; Stansley, P.D.; Holmes, E. Application on NMR-based metabolomics to the investigation of salt stress in maize (Zea mays). Phytochem. Anal. 2011, 22, 214-224. [CrossRef]

55. Abenavoli, M.R.; Sorgona, A.; Albano, S.; Cacco, G. Coumarin differentially affects the morphology of different toot types of maize seedlings. J. Chem. Ecol. 2004, 30, 1871-1883. [CrossRef]

56. Testa, B. The Metabolism of Drugs and Other Xenobiotics; Academic Press: New York, NY, USA, 1995; p. 475.

57. Hammondkosak, K.E.; Jones, J.D.G. Resistance gene-dependent plant defense responses. Plant Cell 1996, 8 , 1773-1791.

58. Kekec, G.; Mutlu, S.; Alpsoy, L.; Sakcali, M.S.; Atici, O. Genotoxic effects of catmint (Nepeta meyeri Benth.) essential oils on some weed and crop plants. Toxicol. Ind. Health 2013, 29, 504-513. [CrossRef] [PubMed]

59. Sunar, S.; Yildirim, N.; Aksakal, O.; Agar, G. Determination of the genotoxic effects of Convolvulus arvensis extracts on corn (Zea mays L.) seeds. Toxicol. Ind. Health 2013, 29, 449-459. [CrossRef] [PubMed]

60. Meazza, G.; Scheffler, B.E.; Tellez, M.R.; Rimando, A.M.; Romagni, J.G.; Li, Y.Z.; Liang, W.J.; Zhang, X.K.; Liu, F.M.; Zhu, X.H. Allelopathic activity of root saponins of alfalfa on wheat, corn and barnyard grass. Allelopath. J. 2005, 15, 119-123.

61. Yu, J.Q.; Ye, S.F.; Zhang, M.F.; Hu, W.H. Effects of root exudates and aqueous root extracts of cucumber (Cucumis sativus) and allelochemicals, on photosynthesis and antioxidant enzymes in cucumber. Biochem. Syst. Ecol. 2003, 31, 129-139. [CrossRef]

62. Wu, F.Z.; Pan, K.; Ma, F.M.; Wang, X.D. Effects of cinnamic acid on photosynthesis and cell ultrastructure of cucumber seedlings. Acta Hortic. Sin. 2004, 31, 183-188.

63. Harun, M.A.Y.A.; Robinson, R.W.; Johnson, J.; Uddin, M.N. Allelopathic potential of Chrysanthemoides monilifera subsp. monilifera (bone seed): A novel weapon in the invasion processes. S. Afr. J. Bot. 2014, 93, 157-166. [CrossRef]

64. Sunmonu, T.O.; Van Staden, J. Phytotoxicity evaluation of six fast- growing tree species in South Africa. S. Afr. J. Bot. 2014, 90, 101-106. [CrossRef]

65. Nonaka, M. Variable sensitivity of Trichoderma viride to Medicago sativa saponins. Phytochemistry 1986, 25, 73-75. [CrossRef]

66. Oleszek, W.; Price, K.R.; Colquhoun, I.J.; Jurzysta, M.; Ploszynski, M.; Fenwick, G.R. Isolation and identification of alfalfa (Medicago sativa L.) root saponins: Their activity in relation to a fungal bioassay. J. Agric. Food Chem. 1990, 38, 1810-1817. [CrossRef]

67. Wyman-Simpson, C.L.; Waller, G.R.; Jurzysta, M.; McPherson, J.K.; Young, C.C. Biological activity and chemical isolation of root saponins of six cultivars of alfalfa (Medicago sativa L.). Plant Soil 1991, 135, 83-94. [CrossRef]

68. Oleszek, W. Allelopathic potentials of alfalfa (Medicago sativa) saponins: Their relation to antifungal and hemolytic activities. J. Chem. Ecol. 1993, 19, 1063-1074. [CrossRef] [PubMed]

69. Waller, G.R.; Yang, C.F.; Chen, L.F.; Liou, R.M.; Wu, S.C.; Young, C.C.; Lee, M.R.; Lee, J.S.; Cheng, C.C.; Chou, C.H.; et al. Saponins produced during the life cycle of mungbeans and their role as allelochemicals. Stud. Plant Sci. 1999, 6, 105-130.

70. Waller, G.R.; Yang, C.F.; Chen, L.F.; Su, C.H.; Liou, R.M.; Wu, S.C.; Young, C.C.; Lee, M.R.; Lee, J.S.; Waller, G.R.; et al. Allelopathic activity of root saponins from alfalfa (Medicago sativa L) on weeds and wheat. Bot. Bull. Acad. Sin. 1993, 34, 1-11.

71. Scognamiglio, M.; D’Abrosca, B.; Fiumano, V.; Chambery, A.; Severino, V.; Tsafantakis, N.; Pacifico, S.; Esposito, A.; Fiorentino, A. Oleanane saponins from Bellis sylvestris Cyr. and evaluation of their phytotoxicity on Aegilops geniculata Roth. Phytochemistry 2012, 84, 125-134. [CrossRef]

72. Ohana, P.; Delmer, D.P.; Carlson, R.W.; Glushka, J.; Azadi, P.; Bacic, T.; Benziman, M. Identification of a novel triterpenoid saponin from Pisum sativum as a specific inhibitor of the diguanylate cyclase of Acetobacter xylinum. Plant Cell Physiol. 1998, 39, 144-152. [CrossRef]

73. Macias, F.A.; Castellano, D.; Molinillo, J.M.G. Search for a standard phytotoxic bioassay for allelochemicals. Selection of standard target species. J. Agric. Food Chem. 2004, 48, 2512-2521. [CrossRef]

74. Takahashi, L.; Sert, M.A.; Kelmer-Bracht, A.M.; Bracht, A.; Ishii-Iwamoto, E.L. Effects of rutin and quercetin on mitochondrial metabolism and on ATP levels in germinating tissues of Glycirte Max. Plant Physiol. Biochem. 1998, 36, 495-501. [CrossRef] 
75. Hussain, M.I.; Reigosa, M.J. Plant secondary metabolite rutin affects the photosynthesis and excitation energy flux responses in Arabidopsis thaliana. Allelopath. J. 2016, 38, 215-228.

76. Ohana, P.; Delmer, D.P.; Volman, G.; Benziman, M. Glycosylated triterpenoid saponin: A specific inhibitor of diguanylate cyclase from Acetobacter xylinum. Biological activity and distribution. Plant Cell Physiol. 1998, 39, 153-159. [CrossRef]

77. Adel, M.M.; Sehnal, F.; Jurzysta, M. Effects of alfalfa saponins on the moth Spodoptera littoralis. J. Chem. Ecol. 2000, 26, 1065-1078. [CrossRef]

78. Golawska, S. Deterrence and toxicity of plant saponins for the pea aphid Acyrthosiphon pisum Harris. J. Chem. Ecol. 2007, 33, 1598-1606. [CrossRef]

79. Sen, S.; Makkar, H.P.S.; Becker, K. Alfalfa saponins and their implication in animal nutrition. J. Agric. Food Chem. 1998, 46, 131-140. [CrossRef]

80. Tava, A.; Odoardi, M. Saponins from Medicago sp.: Chemical characterization and biological activity against insects. In Saponins Used in Food and Agriculture; Waller, G.R., Yamasaki, K., Eds.; Plenum Press: New York, NY, USA, 1996; pp. 97-109.

81. Agrell, J.; Oleszek, W.; Stochmal, A.; Olsen, M.; Anderson, P. Herbivore-induced responses in alfalfa (Medicago sativa). J. Chem. Ecol. 2003, 29, 303-320. [CrossRef]

82. De Geyter, E.; Geelen, D.; Smagghe, G. First results on the insecticidal action of saponins. Commun. Agric. Appl. Biol. Sci. 2007, 72, 645-648.

83. Gorski, P.M.; Miersch, J.; Ploszynski, M. Production and biological activity of saponins and canavanine in alfalfa seedlings. J. Chem Ecol. 1991, 17, 1135-1143. [CrossRef]

84. Golawska, S.; Lukasik, I.; Leszczynski, B. Effect of alfalfa saponins and flavonoids on pea aphid. Entomol. Exp. Appl. 2008, 128, 147-153. [CrossRef]

85. Ghimire, B.K.; Yu, C.Y.; Chung, I.M. Assessment of the phenolic profile, antimicrobial activity and oxidative stability of transgenic Perilla frutescens L. overexpressing tocopherol methyltransferase ( $g$-tmt) gene. Plant Physiol. Biochem. 2017, 118, 77-87. [CrossRef]

86. Tava, A.; Avato, P. Chemical and biological activity of triterpene saponins from Medicago species. Nat. Prod. Commun. 2006, 1, 1159-1180. [CrossRef] 